\title{
STRENGTHENING THE ISLAMIC DIGITAL PAYMENT SYSTEM THROUGH SHARIA ELECTRONIC WALLET (E-WALLET)
}

\author{
Firsty Izzata Bella1, Nadya Fira Efendi ${ }^{2}$ \\ ${ }^{1}$ Faculty of Economics and Business, Universitas Airlangga \\ Airlangga Street, Surabaya, East Java, 60286, Indonesia \\ ${ }^{2}$ Master in Islamic Finance Practice, International Centre for \\ Education in Islamic Finance (INCEIF) \\ Lorong Universiti A, Petaling Jaya, Kuala Lumpur, 59100, Malaysia
}

$\triangle$ Corresponding Author:

Nama Penulis: Firsty Izzata Bella

E-mail: firsty.izzata.bella19@feb.unair.ac.id

\begin{abstract}
The objective of this research is to propose a strategy to strengthen the islamic digital wallet or electronic wallet (e-wallet) in Indonesia to compete with its conventional counterparts. Qualitative research methods with study literature were chosen to explore previous research that had been discussed on e-wallets particularly from the Islamic perspective both at global and national levels through reputable journals, reports, and other supportive documents. The results depicted that the Islamic e-wallet can be optimized through four points, namely promotion, education, collaboration, and trust but remained fulfilling sharia compliance so that the values of Islamic teachings are not vanished. Promotions in the form of cashback can be substituted for points to be converted into donations through the Islamic crowdfunding platform. Education can be improved through social media platforms. The way is by coordinating with Islamic public figures, collaboration with merchants and service providers. Finally increasing trust by safeguarding user data and funds.
\end{abstract}

Keywords: E-Wallet; Digital Payment System; Electronic Money

\begin{abstract}
Abstrak
Tujuan dari penelitian ini adalah mengusulkan strategi untuk memperkuat dompet digital syariah atau dompet elektronik ( $e$-wallet) di Indonesia agar dapat bersaing dengan mitra konvensional. Metode penelitian kualitatif dengan studi literatur dipilih untuk mendalami penelitian-penelitian terdahulu yang telah dibahas mengenai $e$-wallet, khususnya dari perspektif Islam baik di tingkat global maupun nasional melalui jurnal, laporan, dan dokumen pendukung lainnya yang bereputasi baik. Hasil penelitian menggambarkan bahwa $e$-wallet Islami dapat dioptimalkan melalui empat poin yaitu promosi, edukasi, kolaborasi, dan amanah namun tetap memenuhi syariah sehingga nilainilai ajaran Islam tidak sirna. Promosi dalam bentuk cashback dapat disubstitusikan poin yang akan diubah menjadi donasi melalui platform crowdfunding Islami. Edukasi dapat ditingkatkan melalui platform media sosial. Cara yang dapat dilakukan yaitu berkoordinasi dengan tokoh
\end{abstract}


masyarakat Islam, kolaborasi dengan merchant dan penyedia layanan. Pada akhirnya, akan meningkatkan kepercayaan dengan menjaga data dan dana pengguna.

Kata kunci: Dompet Digital; Sistem Pembayaran Digital; Uang Elektronik

\section{INTRODUCTION}

The Global Islamic Economy Report 2019/2020 shows that Indonesia is ranked 5th as the country with the world's best Islamic finance indicators, indicating that there is a significant increase which previously positioned in the 10th in 2018. One of the factors supporting this is the strengthening of the halal economy in each sector formulated through the Halal Economy Masterplan of 2019-2024. It is possible to be achieved since Indonesia has the biggest Muslim population reaching around $87 \%$ of 273 million people, this is a potential market share for sharia-based products and services, including Islamic digital payment systems such as e-money or e-wallet.

Indonesia, like other countries that have preceded it, is starting to move towards a cashless society by maximizing the use of digital payment systems to reduce cash payments. It was recorded on the official website of Bank Indonesia (BI), that in 2020 there were 51 Electronic Money (BI, 2020a) issuer companies with an average overall transaction from January to May 2020 reaching IDR 15 trillion (BI, 2020b).

Figure 1. is the chart shows E-Money transaction in Indonesia according to its nominal and volume from 2013 to 2019.

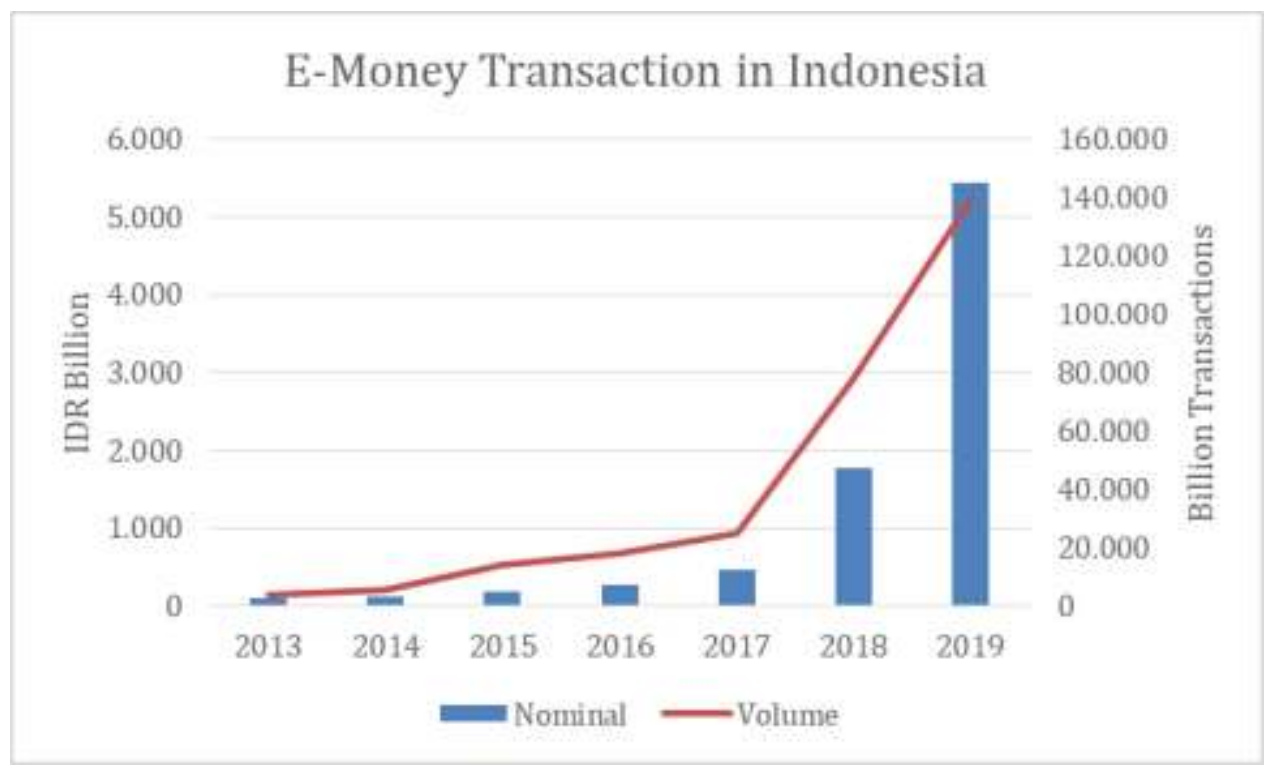

Figure 1. E-Money Transaction in Indonesia 2013-2019

Source: Processed data, Bank Indonesia (2019) 
From the Figure 1, it can be seen that both the nominal and volume of EMoney transaction in Indonesia has grown rapidly over the years with a significant increase in 2019 that reach almost $400 \%$ or four times higher from the previous year. The data indicates that Indonesian people are in the process of moving towards cashless society as other countries in the world. Moreover, it is also depicted that most Indonesian people especially those who live in the city already reduce the cash-payment.

The data as disclosed above becomes an opportunity for sharia finance to broadcast Islamic economic teaching in Indonesia by issuing sharia-based electronic money. This is carried out to avoid riba (interest) remained in the existed e-money. At the end of 2019, under the state-owned company the first and only Islamic payment service in Indonesia issued namely LinkAja Syariah.

Unfortunately, according to a survey conducted by Ipsos Indonesia (Ipsos, 2020), an independent company in the field of marketing research, it is stated that LinkAja only gained a market share of $4 \%$, the smallest compared to Gopay (58\%), OVO (29\%), and Dana (9\%) as other e-wallet issuers. One of the reasons for a large amount of user loyalty to this type of digital wallet (e-wallet) is the promotions, cashback, and discounts offered. Therefore, this study will formulate a strengthening strategy for Islamic Digital Wallet in order to dominate and strengthen the non-cash payment system in Indonesia while still meeting sharia compliance refers to the DSNMUI Fatwa No. 116 of 2017 concerning Sharia Electronic Money.

The majority of previous studies are remained focusing on e-wallet in a general concept such as a research conducted by Alam et al. (2021) in Malaysia using a SWOT (Strengths, Weaknesses, Opprtunities, and Threats) analysis. Meanwhile, Indonesia as the biggest moslem populated country in the world has a gerat potential to strengthen economic growth by optimizing Financial technology (Darmansyah et al., 2020) including Islamic E-money as a payment system. This phenomenon is supported by Aji et al. (2020) research which concludes that Indonesian citizen are getting aware and knowledgeable about riba in using E-Money. Additionally, the paper also gives a suggestion for government to release the Sharia-compliant e-money which currently available and will be discussed in this research. Moreover, Ali et al. (2021) recommend to conduct a research on the field of Islamic finance including digital payment in the form of e-wallet. However, despite of several supporting data and findings from the earlier studies, this paper aimed to fill the gap by proposing the idea to strengthen Indonesian Islamic digital payment system or e-wallet which to the best of author's knowledge has not been discussed before. 


\section{LITERATURE REVIEW}

From a historical perspective, cashless-based transactions have been practiced for a long time precisely in the 1860s, when the Western Union company introduced an electronic fund transfer system, then it was continued in the late 1990s through the use of electronic checks and smart cards to transfer money (Ulfi, 2020). Meanwhile, in Indonesia, the e-money payment system emerged in 2009 in line with the issuance of Bank Indonesia regulations, which at that time were still chip-based. The application/serverbased e-money was first born in 2017 through a product called Tcash by Telkomsel eventually changed its name in 2019 to LinkAja (Putra et al., 2020).

Janine Firpo, an author, investor, and social entrepreneur in her article on the World Bank blog concludes the definition of e-money as a monetary value that is stored electronically on receipts of funds, and which is used for making payment transactions which can be held on cards, devices, or on a server. Furthermore, he also specifically defines Electronic Wallet (e-wallet) as the cash value that is stored on a card, phone, or other electronic devices, including pre-paid cash. The term wallet is used because the card or phone is considered a substitute for the cash normally carried in a person's wallet (Firpo, 2009). Forrester Research, an American market research company, defines a digital wallet payment as a non-cash payment that allows customers to purchase their smartphones or other devices by acting as an electronic wallet, digitizing payment information (Forrester Research, 2017).

There are at least six main advantages of e-wallet for customer (Bakar et al., 2020): first, E-wallet is digital payments for a safer, cashless, and efficient transaction, second, Ease of transaction tracking to monitor user expenses because it provides a record for every transaction, third, E-wallet provides user-friendly cash reload system using cash, debit/credit card, and bank transfer, fourth, E-wallet is backed by a money-back guarantee system by a provider. Therefore, users can perform a payment process confidently with enhanced security features. Fifth, E-wallet provides a money transfer process that covers a broad range of products and services. The vast network of e-wallet payments makes a better user experience for payment transactions. Lastly, the E-wallet payment method also supports peer fund transfers that enable smooth cash movement among users of the e-wallet system.

\section{METHOD}

The research applied a qualitative approach to discover in-depth insights on the phenomenon of interest (Yin, 2014), which was specifically 
carried out through descriptive method and literature study, or researcher reading and studying the existing literature while developing the new concept or idea to maximize and improve the object of study. Information and data are collected through written texts, as well as soft copy editions such as books, e-books, articles, magazines, newspapers, journal papers, internet media, report and so on (Akmal et al., 2020) which explains e-wallet or e-money from an Islamic perspective. Finally, the data are analyzed by compiling the strategy on how strengthening the Digital Islamic Payment particularly in the form of e-wallet.

The study provides an optimization concept for strengthening Islamic Digital Payment which specifically discusses Digital Wallet (e-money) currently in Indonesia, namely LinkAja Syariah, however, the results of this study are not limited to a specific object, but globally to the Islamic E-Money that may be proposed in the future.

\section{RESULT AND DISCUSSION}

\section{Indonesia Towards a Cashless Society}

Digital Payment has been recognized and has begun to be implemented as a new trend in Indonesia, even since 2014 the Governor of Bank Indonesia has declared the "Gerakan Nasional Non-Tunai (GNNT)" to increase public awareness of the use of non-cash instruments so that a community or society will gradually form. who prefer to use non-cash instruments (Less Cash Society/LCS)

Initially, there is only one type of e-money in Indonesia, which is made and used in the form of card and most people used it as the payment method for using transportation such as Busway, Commuterline (KRL), toll, retail purchase, and others. Moreover, by the advance of technology, the e-money developed into another category known as an e-wallet that can be used as any payment both online or offline transaction.

One form of electronic-based payment is electronic money (e-money), which is officially a non-cash payment instrument such as cards, checks, billet giro, and debit notes. Electronic money products are specifically divided into two types, namely: 1) Chip-based, namely products that use identical chips in the form of cards such as Flazz from BCA, E-money/E-toll from Mandiri, Brizzi from BRI, and so on; and 2) Server-based, namely server-based or applications such as Gopay, Ovo, LinkAja, and Dana which are known as ewallets. The explanation is contained in Figure 2.

The second category is the main object of this research, which is serverbased e-money that will be referred to as e-wallet. Reports issued by Bank Indonesia from year to year show a significant increase in the volume of ewallet based transactions. By looking forward to the Bank Indonesia report 
for nominal data on electronic money transactions from 7 years ago, 20132019 , it can be seen that there has been a very large increase, namely $715 \%$ or 70 times, which initially amounted to IDR 2 million in 2013 to IDR 145 million in 2019 (BI, 2020b).

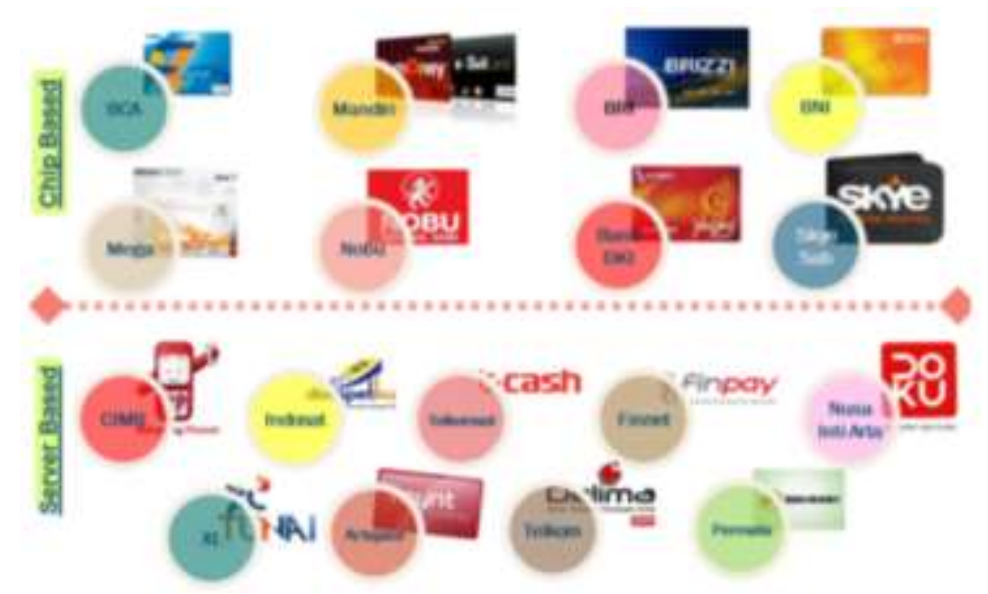

Figure 2. Some Products of E-Money (Chip Based) and E-Wallet (Server Based) in Indonesia Source: Bank Indonesia (2020)

Currently, by the development of e-money, Bank Indonesia (BI) has issued an amendment to the E-Money regulation as contained in Bank Indonesia Regulation (PBI) No. 20/6/PBI/2018 concerning Electronic Money (BI, 2018), therefore all of the implementations should refer to the above regulation in order to ensure that the industry can provide the greatest contribution towards the national economy of Indonesia.

The above notion shows that the Indonesian communities are very enthusiastic about utilizing e-money as a payment method for transactions so that the goal of becoming a cashless society is getting closer to being realized. The research results of Putra et al (2020) show that the ease of transaction factor is the main reason for using LinkAja e-money with a percentage of $45 \%$, followed by a discount on the product offered by $42 \%$, as for other reasons with an average score below 5\%, namely the level safety, comfort, experience and lastly a lifestyle (Putra et al., 2020).

\section{Digital Wallet Practices from an Islamic Perspective}

A study by Bakar et al. (2020) concluded that from Islamic financial engineering, transactions using an e-wallet is a secure system without a doubt since all the transaction process provides a clear, traceable, and reliable transaction method (Bakar et al., 2020). However, it can also have a negative effect on consumptive behavior if it triggers a wasteful lifestyle. Islam sets limits in the consumption behavior of Muslims, one of which is the 
halalness of the product and not excessive (tabzir), so that all transactions must be carried out fairly (Amelia et al., 2020). This is as stated in the QS. AlIsra 'verse 26 which reads:

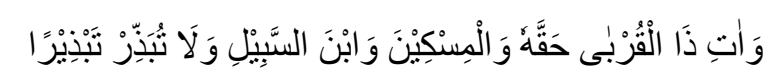

"And give the relative his right, and [also] the poor and the traveler, and do not spend wastefully." (QS. Al-Isra:26)

LinkAja Syariah, issued by PT. Fintek Karya Nusantara, has become the first and only sharia e-wallet product in Indonesia since the end of 2019. The difference between LinkAja Syariah and LinkAja (conventional) and other ewallets that have been circulating are first, the transactions without usury and already pocketing DSN MUI and BI certificates, second, funds are collected at Islamic banks, third, the payment is accepted at all LinkAja merchants according to sharia regulations, and last, fill in balances from and to all Banks, including Sharia Banks. The certificates is showed by Figure 3.

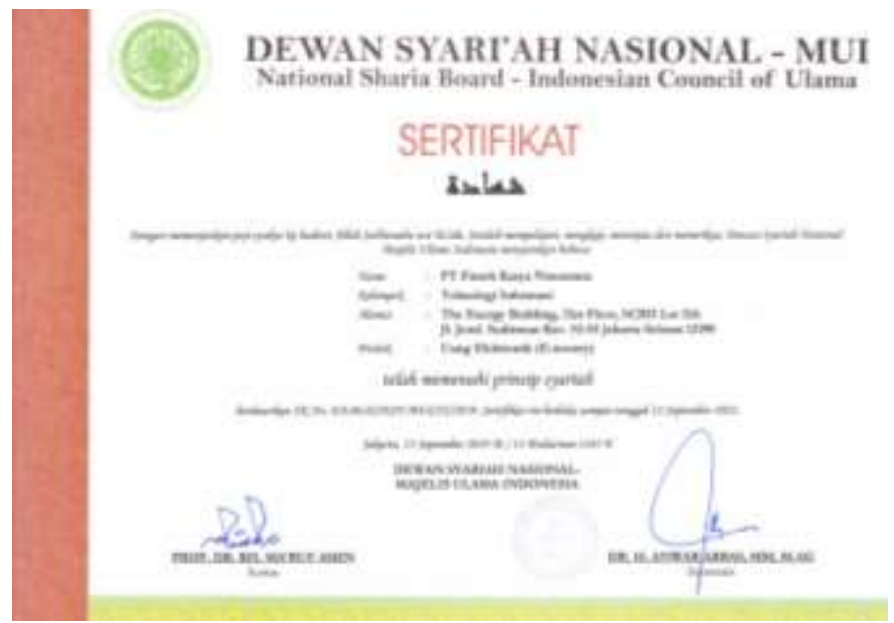

Figure 3. Certification for Sharia Compliance of E-Wallet LinkAja Syariah Source: DSN-MUI (2019)

The presence of LinkAja Syariah is required and refereed to DSN-MUI Fatwa No. 116/DSN-MUI/IX/2017 on Sharia E-Money since the other ewallet are remained to apply conventional method which contained riba especially for the cashback and discount offered by the issuer categorized as an excess/addition/advantage since the initial agreement between user/consumer and e-money provider is qardh (debt). However, Aji (2019) argues that the transaction between user and provider is not qardh but ijarah (exchange of service). Consequently, the discount or cashback given by the provider to the users is not considered as riba, yet it is allowed and halal (Aji, 2019).

Moreover, its existence also supports the 2019-2024 Indonesian Sharia Economic Master Plan formulated by the "Komite Nasional Ekonomi dan 
Keuangan Syariah" (KNEKS) with the aim of advancing the sharia economy in Indonesia, one of which is one of the main priorities of increasing the efficiency of Islamic finance (Komite Nasional Keuangan Syariah, 2018). Even so, Islamic e-money must certainly meet Islamic business ethics which consists of four axioms (Zulni \& Achiria, 2020), namely: 1) Unity, without discriminating against ethnicity, religion, race and culture, 2) Justice or balance, between its functions as a sale and purchase transaction and social funds. , 3) Free will, namely working with halal merchants to get the pleasure of Allah, and 4) Responsibility for funds and user data.

Supplementary to this, the features offered by LinkAja Syariah are fairly complete, such as the ZISWAF (collection \& distribution) ecosystem, mosquebased economic empowerment, digitization of Islamic boarding schools and SMEs, investment and sharia insurance, and Umrah / Haj payments, although some of them are still in the process and will be coming soon.

\section{Strategy to Strengthen Islamic Digital Wallet (E-Money)}

From various previous studies that have been analyzed by researchers, there are at least four important points that should be considered in strengthening the practice of Islamic Electronic Money specifically for serverbased, namely: 1) Promotion, 2) Education, 3) Collaboration, and 4) Trust.

\section{Promotion}

Several researchs show that promotional variables including advertisements, discounts, membership points, and rewards are the main attraction for users, especially in choosing which payment products (e-wallets) to use (Susanto et al, 2020; Utami, 2019) . Hence, it is important for LinkAja Syariah products to increase promotion through advertisements, especially on various social media as well as offering offers in the form of discounts and cashback or points. This is supported by other studies which conclude that consumers tend to have a greater intention to switch to e-wallet products if the cashback offered is greater than its competitors (Ulfi, 2020).

In contrast, as stipulated in the DSN-MUI Fatwa No. 116 of 2017 concerning Islamic Electronic Money states that cashback or discounts given to customers must be given by merchants and not by card issuers. Then the form of cashback can be replaced with points given by the seller, which can then be donated via crowdfunding platforms such as Kitabisa, Ammana, and so on. Ergo, the points given can also be used as a seller as a Corporate Social Responsibility program.

Besides, including in terms of promotion that is user-friendly, as research says that when users have difficulty using e-money, there is 
less desire to use it (Djamaluddin et al., 2016). Therefore, the issuer should simplify registration, access, and the features available so that the Islamic e-wallet can be used by various levels of society, across ages, and reaches all the corners of Indonesia.

Moreover, by looking forward to the official website of LinkAja Syariah, it is mentioned that there are many provided platforms or institution to donate in this application such as Rumah Zakat, Human Initiative, ACT, BAZNAS, Dompet Dhuafa, and so on. Therefore, replacing cashback in the form of money to point as a donation can be used as an option to avoid riba.

\section{Education}

Another important thing that is the main point for Islamic Digital Payment to be widely used by the community is to increase public literacy about sharia financial studies to always prioritize the use of sharia-based financial services over conventional ones. Although the results of a study indicate that the Muslim community has started to have awareness and already understands the practice of ribawi (Aji et al., 2020), the object of this research is dominated by students and has not been able to represent all Muslims at every level of society in Indonesia.

The education and seminar can be in the form of campaigns and collaboration with stakeholders, policymakers, government, and influencers on social media to always echo the sharia e-wallet. Many of the studies show that campaigns or marketing through social media have a big influence on society in their behavior (Jones et al, 2015; Keegan \& Rowley, 2017), especially with research conducted by We Are Social and Hootsuite which states that as of January 2020 as many as $59 \% \%$ of Indonesia's population or reaching 160 million people have utilized social media from a population of 272.1 million Indonesians, with the five most used platforms, namely Youtube, Whatsapp, and Facebook, Instagram, and Twitter (Hootsuite, 2020).

From the statistics above, it is clear that the strategy that must be taken through education is the main way to utilize the digital platform that is most widely used by the people of Indonesia, with that, Islamic financial inclusion, one of which is the use of Islamic e-wallets, can be increased and beat its conventional competitors. This strategy also supported by Rafdinal \& Senalasari (2021) which concluded that by facilitating through videos on social media such as Youtube, Instagram, Twitter etc, about the step-by-step instruction, the increase number of user will be existed. 


\section{Collaboration}

There are several of collaboration and cooperation that issuer can do with various parties, such as with various merchants, especially those with a strong customer base (Widyastuti et al., 2017). With the involvement of several Sharia Banks, it is also expected that the fees charged to cardholders such as top-up fees, transfers, etc. can be minimized, so it is hoped that it will increase interest in using Islamic emoney.

Other parties that can be used as collaboration partners are Islamic public figures in promoting Islamic e-wallet products to increase public awareness of the importance of using Islamic financial services and provide peace and blessings in transactions. Moreover, Sharia e-wallet can also coordinate with other business partners which provided different halal products and services such as 212 Mart, sharia hotel, and even Small and Medium Enterprises (SMEs). This collaboration must be existed in the form of infrastructure hence, people can easily make a transaction using e-wallet (Alam et al., 2021)

To conclude, a beneficial collaboration can be made with Payment Point Online Bank (PPOB), E-commerce, transportation, donation, public service, and installment or loan as long as it meets Sharia compliance. By increasing this strategy, it is hoped that the user can be more attracted to utilize LinkAja Sayriah or the upcoming Islamic ewallet rather than the conventional one.

\section{Trust}

Alam et al. (2021) argued that protection, safety of the data, a customer privacy and othes risks related to financial loss should be taken into high consideration for all digital payment provider. Moreover, a study conducted by Reskyana (2020) shows that the reputation of a product and a publishing company is a major factor in increasing the level of user confidence in continuing to use the LinkAja e-wallet product which is then followed by mobility, security, and customization variables. This is also supported by other research which states that brand trust has a positive effect on brand commitment, means that trust will impact the intention and use of the product in the long term particularly in Islamic Fintech (Ali et al., 2021; Putra et al., 2020).

From some of the studies above, the writer argues that LinkAja Syariah, which is under the auspices of a red plate company, has quite a good reputation, but there is a need for an increase in public trust in the use of this payment method, one of which is through fast, responsive 
customer service or response. and responsive to complaints or violations, even implementing a 100\% money-back guarantee (Samsumar, 2016). Furthermore, another study adds that the issuing company must guarantee data security and customer and customer privacy by providing clear rules.

This is in line with the research of Darmansyah et al. (2020) which states that in order to increase people's intention to use the Islamic Digital Payment system, the publisher must increase the level of security, prestige, user-friendliness and the aesthetics on the server provided. Forrester Research (2017) says that e-wallet issuers must echo and prove to merchants as a seller and customer as a buyer how the technology works and why this payment method is safer to use for online and offline payments

\section{CONCLUSION}

With the development of times and advances in technology, cash payments are slowly starting to be replaced by digital payments, one of which is a digital wallet (e-wallet). This payment method is not only used for online transactions, but also offline (in-store purchases), but unfortunately, Islamic e-wallets have not been widely used by Indonesians when compared to conventional competitors. Therefore, some of the efforts or strategies that the authors propose in this study cover at least four points, namely promotion, education, collaboration, and trust. Promotions can be carried out by replacing cashback with points that can be converted into nominal money to be donated with cooperative platforms, and through developing applications with user-friendly features and usage. Education can be carried out through non-digital and digital platforms such as social media which is widely used by the community in the form of an invitation campaign to use Islamic e-wallets. Next is a collaboration with Islamic public figures who have good reputations and are known by the public in increasing the intention to use Islamic e-wallets. And the last one is trust in Islamic e-wallet products and issuing companies, one of which is through user security and comfort.

Some policy recommendations that can be carried out by the government are first, to help promote Islamic e-wallet while supporting economic growth and sharia finance in Indonesia. Second, injecting business funds as capital for LinkAja Syariah as the only existing Islamic e-wallet that is under the ownership of BUMN. Third, increase education and inclusion of Islamic finance by facilitating the provision of seminars, workshops, and training for academics, practitioners, and the general public. And finally, it supports the performance of Sharia' e-wallet by synchronizing payments for 
several public services such as PLN, PDAM, BPJS, and so on by providing discounts or cashback and other benefits to users.

\section{REFERENCES}

Aji, H. M., Berakon, I., \& Riza, A. F. (2020). The effects of subjective norm and knowledge about riba on intention to use e-money in Indonesia. Journal of Islamic Marketing, 12(6), 1180-1196. https://doi.org/10.1108/JIMA10-2019-0203

Aji, H. M. (2019). E-Money and 'riba': Understanding the business model. The Jakarta Post. https://www.thejakartapost.com/academia/2019/04/ 08/e-money-and-riba-understanding-the-business-model.html

Akmal, H., Mellina, T., Jamal, M., Zarkasyi, H. F. (2020). Konsep Penjagaan Terhadap Harta Dalam Wisata Syariah. IJTIHAD, 14(1), 1-20. https://doi.org/10.21111/ijtihad.v14i1.4501

Alam, M. M., Awawdeh, A. E., \& Muhamad, A. I. B. (2021). Using e-wallet for business process development: challenges and prospects in Malaysia. Business Process Management Journal, 27(4), 1142-1162. https://doi.org/10.1108/BPMJ-11-2020-0528

Ali, M., Raza, S. A., Khamis, B., Puah, C. H., \& Amin, H. (2021). How perceived risk, benefit and trust determine user Fintech adoption: a new dimension for Islamic finance. Foresight, 23(4), 403-420. https://doi.org/10.1108/FS-09-2020-0095

Amelia, Fitri; Fikriyah, K. (2020). Hubungan Promo Cashback Terhadap Loyalitas Pelanggan Muslim Surabaya Dalam Pelayanan Digital Wallet Ovo. Jurnal Ekonomika Dan Bisnis Islam, 3(2), 108-115.

Bakar, N. A., Rosbi, S., \& Uzaki, K. (2020). E-Wallet Transactional Framework for Digital Economy: A Perspective from Islamic Financial Engineering. International Journal of Management Science and Business Administration, 6(3), 50-57. https://doi.org/10.18775/ijmsba.18495664-5419.2014.63.1005

Bank Indonesia. (2018). Peraturan Bank Indonesia Nomor 20/6/PBI/2018 tentang Uang Elektronik. In Bank Indonesia.

Bank Indonesia. (2020a). Daftar Penerbit Uang Elektronik. https://www.bi.go.id/id/statistik/sistem-pembayaran/uang-

elektronik/contents/penyelenggara uang elektronik.aspx

Bank Indonesia. (2020b). Total Transaksi Uang Elektronik. https://www.bi.go.id/id/statistik/sistem-pembayaran/uangelektronik/contents/transaksi.aspx

Darmansyah, F. B. A., Hendratmi, A., \& Aziz, P. F. (2020). Factors determining behavioral intentions to use Islamic financial technology: Three competing models. Journal of Islamic Marketing. 12(4), 794-812. https://doi.org/10.1108/JIMA-12-2019-0252

Djamaluddin, S., Hidayanto, A. N., \& Wardhani, S. (2016). Perception of beneficiaries towards adoption of e-money in the distribution of social assistance in Indonesia. Economic Journal of Emerging Markets, 8(1), 13-24. https://doi.org/10.20885/ejem.vol8.iss1.art2 
Firpo, J. (n.d.). E-Money - Mobile Money - Mobile Banking - What's the Difference? World Bank Blogs. Retrieved July 3, 2020, from https://blogs.worldbank.org/psd/e-money-mobile-money-mobilebanking-what-s-the-difference

Forrester Research. (2017). The Next Phase Of Digital Wallet Adoption (Issue September).

Ipsos. (2020). Ipsos Media Conference - Strategi Menang Tanpa Bakar Uang. Retrieved July 3, 2020, from https://www.ipsos.com/en-id/ipsosmedia-conference-strategi-menang-tanpa-bakar-uang

Jones, N., Borgman, R., \& Ulusoy, E. (2015). Impact of social media on small businesses. Journal of Small Business and Enterprise Development, 22(4), 611-632. https://doi.org/10.1108/JSBED-09-2013-0133

Keegan, B. J., \& Rowley, J. (2017). Evaluation and decision making in social media marketing. Management Decision, 55(1), 15-31. https://doi.org/10.1108/MD-10-2015-0450

Komite Nasional Keuangan Syariah. (2018). Masterplan Ekonomi Syariah Indonesia 2019-2024. In Kementerian Perencanaan Pembangunan Nasional/ Badan Perencanaan Pembangunan Nasional.

Putra, H. D., Kusumawati, A., Astuti, E. S., \& Abdillah, Y. (2020). Effect of brand trust and commitment of a mobile wallet in Indonesia. Utopia y Praxis Latinoamericana, 25(Extra 2), 397-405. https://doi.org/10.5281/ zenodo.3815290

Putra, H. D., Astuti, E. S., Kusumawati, A., \& Abdillah, Y. (2020). Knowing the reasons of using E money LinkAja in Indonesia. Talent Development and Excellence, 12(3), 242-250.

Rafdinal, W., \& Senalasari, W. (2021). Predicting the adoption of mobile payment applications during the COVID-19 pandemic. International Journal of Bank Marketing. https://doi.org/10.1108/IJBM-10-20200532

Reskyana, N. C. (2020). Analysis of Factors Affecting Continuance Usage Intention of LinkAja Applications. Almana: Jurnal Manajemen Dan Bisnis, 4(1), 17-28.

Samsumar, L. D. (2016). Konsep Dan Tantangan Penggunaan Teknologi EMoney Sebagai Alat Pembayaran Alternatif Di Indonesia. METHODIKA: Jurnal Teknik Informatika Dan Sistem Informasi, 2(1), 102-107.

Susanto, P., Hoque, M. E., Hashim, N. M., Shah, N. U., \& Alam, M. N. (2020). Moderating effects of perceived risk on the determinants - outcome nexus of e-money behaviour. International Journal of Emerging Markets. https://doi.org/10.1108/IJOEM-05-2019-0382

Ulfi, I. (2020). Tantangan Dan Peluang Kebijakan Non-Tunai: Sebuah Studi Literatur. Jurnal Ilmiah Ekonomi Bisnis, 25(1), 55-65. https://doi.org/10.35760/eb.2020.v25i1.2379

Utami, M. C. (2019). Implementasi Analytical Hierarchy Process (AHP) Dalam Pemilihan E-Wallet Untuk Mahasiswa. Jurnal Ilmiah Matrik, 21(3), 259265. https://doi.org/10.33557/jurnalmatrik.v21i3.730

Hootsuite. (2020). DIGITAL 2020: INDONESIA. https://datareportal.com/ reports/digital-2020-indonesia 
Widyastuti, K., Handayani, P. W., Wilarso, I. (2017). Tantangan dan Hambatan Implementasi Produk Uang Elektronik di Indonesia: Studi Kasus PT XYZ. Jurnal Sistem Informasi (Journal of Information System), 13(1), 3848.

Yin, R. K. (2014). Case Study Research Design and Methods (5th Editio). SAGE Publications.

Zulni, D., A., \& Achiria, S. (2020). Implementation of Islamic Business Ethics in Digital Wallet: Literature Review Approach. EkBis: Jurnal Ekonomi Dan Bisnis, 3(1), 232-241. https://doi.org/10.14421/EkBis.2019.3.1.1181 